Determination of Vertebral Bone Mineral In Vivo

\author{
by \\ M. G. Ort and J. R. Cameron \\ Department of Radiology \\ University of Wisconsin \\ Madison, Wisconsin \\ $y$
}

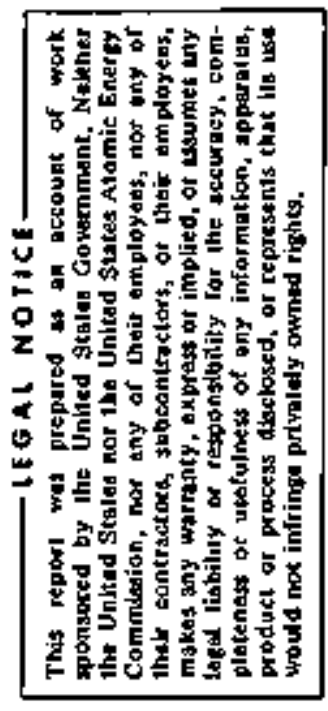

$\cdot$

I. Introduction

Osteoporosis is a disease of the bone in which there is a simultaneous reduction of cortical and spongy bone. McLean and Urist (1) have indicated that the loss of the spongy bone is more rapid than the cortical bone. The vertebral bodies contain a higher percentage of spongy bone than other bones of the body (2). It is therefore believed that skeletal changes might be detected earlier by measuring the bone mineral content of the vertebral bodies rather than other bones. In addition, overt clinical symptoms of osteoporosis usualiy appear first in the spine through collapsed vertebrae ("dowagers hump") and through decreased height. It is the area that is usually examined by a radiologist to make a diagnosis of osteoporosis.

A method of in yivo determination of bone mineral content in the lumbar vertebrae by a linear aichronatic transmisaion scan has been described by Roos (3). In an effort to reproduce and extend his techniques, we have constructed a vertebral bone mineral measuring system. A crucial problem is the accurate localization of the vertebra to be scanned. In our system a fluoroscope and image intensffier are used to locate the vertebra of interest with the subject in a supine position. We are t1sing Gadolinium-153 (Gd-153) with photon energiess of approximately 43 and $100 \mathrm{keV}$ as a dichromatic gamma ray source. The beam is callimated by an adjutable rectangular collimator at the source and at the 2 inch diameter NaI (TI) scintillation crystal, Durang this past year equipuient for these measurements was designed and constructed. Only preliminary results will be presented in this report.

\title{
II. Theory
}

Figures 1 and 2 show the location and structure of the spinal column. Figure 3 depicta a typical thitd lubbar (L-3) vertebra of an aoult male. The L-3 vertebra is an irregular body of about 3 by $9 \mathrm{~cm}$ as viewed by the source-detect or system. The source and detector collimators were designed to produce a beam $3 \mathrm{~cm}$ by $1 \mathrm{~cm}$ at the level of L-3 and the vertebra is scanned laterally a distance of about $20 \mathrm{~cm}$. The results of the transmission messurements of both energies are then processed to give the bone mineral content of the vertebra.

The equations for the determination of the amount of bone mineral and/or soft tissve in the path of a dichromatic beam have been previously described by Judy (4) and Roos (3). These equations are:

* This source is further described in USAEC Report co0-1422-71 (1970). 


\section{DISCLAIMER}

This report was prepared as an account of work sponsored by an agency of the United States Government. Neither the United States Government nor any agency Thereot, nor any of their employees, makes any warranty, express or implied, or assumes any legal liability or responsibility for the accuracy, completeness, or usefulness of any information, apparatus, product, or process disclosed, or represents that its use would not infringe privately owned rights. Reference herein to any specific commercial product, process, or service by trade name, trademark, manufacturer, or otherwise does not necessarily constitute or imply its endorsement, recommendation, or favoring by the United States Government or any agency thereof. The views and opinions of authors expressed herein do not necessarlly state or reflect those of the United States Government or any agency thereof. 


\section{DISCLAIMER}

Portions of this document may be illegible in electronic image products. Images are produced from the best available original document. 


$$
\begin{aligned}
& M_{\mathrm{HM}}=\mathrm{K}_{\mathrm{t}} \log _{\mathrm{e}}\left(\mathrm{I}_{0} / I\right)+\mathrm{K}_{2} \log _{\mathrm{e}}\left(\mathrm{I}_{\mathrm{o}}^{\prime} / \mathrm{I}\right) \\
& \mathrm{M}_{\mathrm{ST}}=\mathrm{K}_{3} \log _{\mathrm{e}}\left(\mathrm{I}_{\mathrm{o}} / \mathrm{I}\right)+\mathrm{K}_{4} \log _{\mathrm{e}}\left(\mathrm{I}_{\mathrm{o}}^{\prime} / \mathrm{I}\right)
\end{aligned}
$$

where

$$
\begin{aligned}
& M=\text { mass in } \mathrm{gm} / \mathrm{cm}^{2} \\
& B M=\text { subscript reierring to bone mineral component } \\
& S T=\text { subscript referring to soft tissue component } \\
& I_{0}=\text { unattenuated intensity for one energy } \\
& I=\text { transinitted intensity for one energy }
\end{aligned}
$$

The primes indicate the second energy quantities,

$$
\begin{aligned}
& \text { and } k_{1}=\frac{\mu_{S T}^{\prime}}{\mu_{S T^{\prime}{ }_{B M}}-\mu_{S T^{\mu}{ }_{B M}^{\prime}}} \\
& \mathrm{K}_{2}=\frac{\mu_{\mathrm{ST}}}{{ }^{\mathrm{ST}^{+}{ }^{\mu} \mathrm{BM}}-{ }^{\mu_{\mathrm{ST}}{ }^{\mu}{ }_{\mathrm{BM}}}} \\
& \mathrm{K}_{3}=\frac{\mu_{\mathrm{BH}}^{\prime}}{\mu_{\mathrm{ST}^{\prime}{ }^{\mu}{ }_{\mathrm{BH}}}-{ }^{\mu_{\mathrm{ST}}{ }^{\mu}{ }_{\mathrm{BH}}^{\dagger}}} \\
& \mathrm{K}_{4}={ }_{\mathrm{BH}}^{\mu_{\mathrm{B}}}
\end{aligned}
$$

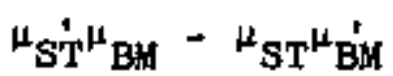

where the $\mu$ and $\dot{\mu}$ are the mass attenuation coefficients. While Roos's equations may appear to be different from Judy's because of the use of different symbols and scaling factors, fundamentally their equations are the game.

Because the above equations for decermining the bone meneral mass assume exponential absorption, it is necessary to determine to what extent the relatively broad bear is attenuated by bone and soft tissue exponentially as a function of thickness. These equations also assume there is no interference between the measurements of the two photon beams. However, with a dichromatic source two photon energies are transulitted simultaneously; one nust therefore correct for "spill over" due to scatter of the higher energy photons into the 
lower energy photon channel. Sone of our absorption mesurements show this effect.

\section{Equiprent}

A small animal fluoroscope was modified for vertebral bone mineral determinations (see figure 4). Thirty-eight centitheters belaw the tabletop of the fluoroscope 8 Gd-153 source holder is mounted on top of the $x-t a y$ tube. The source and holder are removed during the localization of L-3 and then are put back for the bone mineral determination. The holder is reprodtcibly positioned by four pins. Thizty-four centineters above the tabletop both an image intensifier (with a T.V. canera) and a two inch diameter NaI(Tl) crystal (with photomultiplier tube and collimator) are mounted (see figure 5). They are fixed at right angles and are supported by the same vertical column which strpports the $x$-ray head below the table. The image intensifier and $\mathrm{NaI}$ detector can swing in a horizontal plane above the tabletop so that the image intensifier is positioned for localization, after which the detector is moved into the same position for the bone mineral measurements. Accurate repositioning is made possible by the use of a tapered pin. The whole system can be moved in either direction in the horizontal plane. In normal operation the apparatus is moved in the lateral direction by a screwdrive.

The dichromatic source, a $60 \mathrm{nCC}$ Gd-153 source t* wth principal energy peaks at approxinately 43 and $100 \mathrm{keV}$, is initislly collimated by ics 6 min diameter casing and is further collimated by a $1 / 16$ inch thick lead sheet. This collimator is adjusted so that the beam is $3 \mathrm{~cm}$ by $1 \mathrm{~cm}$ at the $\mathrm{L}-3$ height. The photons emerging from the body are then collimated at the detector by a similar rectangular aperture to minimize the scatter.

Proper setting and alignment of the source and collimators is essential. A light source (which can be substituted for the Gd-153 source) was constructed using a prefocused $\$ 222$ miniatere lamp mounted behind a 6 no dianeter plastic translucent window. This 1ight source is inserted into the source holder such that its position and diarueter is the same as the Gdn 153 source. We compared the light source field with an X-ray picture of the Gd-153 bean profile at the L-3 level. The agreement tas excellent; therefore we use the light source for adjusting and aligning the collinators.

The electronic components needed to process the transmission infortation of the Gd-153 source are shown in a black diagrath in figure 6. A dual channel analyzer is needed to separate the two photoelectric peaks. The number of counts in each channel is counced for a fixed time at each measuring point. The information is then fed into a buffer from which it can be elther printed, punched out on paper tape, or recorded on magnet1c tape.

* Continental X-ray Corp., Madel 20-80 Horizontal Fluoroscope 
The inttial meacurement a we made with the equipment ahown in figure 7. Tro Baird Atonic (tiodel 1530 ) tnits, each with a preanplifier, oingle channel analgzer and timer-gcoler, vere used. The unfte were atarted oinultaneously and the number of counte wes recorded manually. In an effort to facilitate the handling of $*$ larger quantity of data, acme method of traneferring the data to punched tope ox magnetic tape was necerary.

The heart of chis new inctrumentation is a multi-channel anslyzer (ate figure 8) that can perfort molti-channel scaling and has a memory capable of 256 aix digit nubers. We use the memory at a buffer. Th1s unit aloo has a oxpgle channel anulyzer which we nodified to autconticaliy alternate between two different singla channel analyzer settings each time the memory locetion io advanced. It is therefore posalble to alternately count and otore the 43 and $100 \mathrm{keV}$ channela. An entire acan can be atored in the analgzer'a 256 memory channelo. The numbers in the memory are then read out into a Teletype model 33ASR using the Interface which is a part of the multi-channel analyzer. Thio produces afmultaneouly a liating and punched paper tape. The paper tope te then fed into a computer for analyals.

The digedventage of thite eyetem is that only the $43 \mathrm{keV}$ or the $100 \mathrm{keV}$ channel can be counted at one time. But this 1s not a serlous limitetion if there are sufficiently bigh count rates and if the oettinge of the oingle channel analyzer are alternated relotively fart with respect to the scaming opeed.

\section{Regults}

The results of abeorption atudies made for water, preoeed board and aluminu for the two onergs peakn of Gd-153 are plotted in figure 9. The higher energy aboorption curves are clearly exponential over at leapt a full decade for thege materials. The olight departure from exponential absorption with increasing absorber thickneas in the lower energy channel oppears to be primarily due to opillover and perhape partly due to the increased algnificance of Imperfect resolution of the two poske. Further experimente are planned to attenpt to quantify the eptllover and tesolution effecto.

Figure 10 it at x-roy phatograph 11 lustrating a phantom of a human trunk we used far a laterel scan of L-3. The top vertebrel body in thin $x$-ray $1=1-3$.

The count rates for the lower and upper energy channela and the calculated bone nineral are ghown in Figure 11. We counted for one ninute at each $1 \mathrm{~cm}$ interval. The moximum change in count rate for etther channel 1o leee than a factor of 2 . Over this Ifmited range it oppeara that exponential aboorption in both energy channels is a reagonable agutuption.

* Northern ScLentific model NS600 
V. Future Plans

We plan to continue our work in evaluating sources of error and performing calibration gtudies. Because the small fluoroscope we were using is not intense enough we plan to use a more intense patient fluoroscope for localization. In an effort to decresse the errors due to repositioning we are planning to build a new scanner capable of area scans in addition to linear scans. We will also scan other bones containing high percentage of spongeosa, such as the cervical spine and the aeck of the femur.

This work was supported in part by the U. S. Atomic Energy Commission through contract AT- $(11-1)=1422$, 
1. Mctean, F.C. and Urist, M.R., Bone, 3rd ed., p. 239, The Un1vergtity of. Chicago Press, Chicago, 1968.

2. Gong, J.K., Arnold, J.S., and Cohn, S.H., Cotuposition of Trabecular and Cortical Bone, Anatomical Record 149: 325-332 (1964).

3. Roos, B., Rosengren, B., and Sköldborn, H., Determination of Bone Mineral Content in Lumbar Vertebrae by a Double Gama-Ray Technique, in Proc. of Bone Measurement Conference, Cameron, J.R., ed. pp. 243-254, USAEC CONF-700515 (1970). In press.

4. Judy, P.F. and Cameron, J.R., A Dichromatic Absorption Method for the Measurement of Bone Mineral Content, USAEC Report c00-1422-60, (1969). 


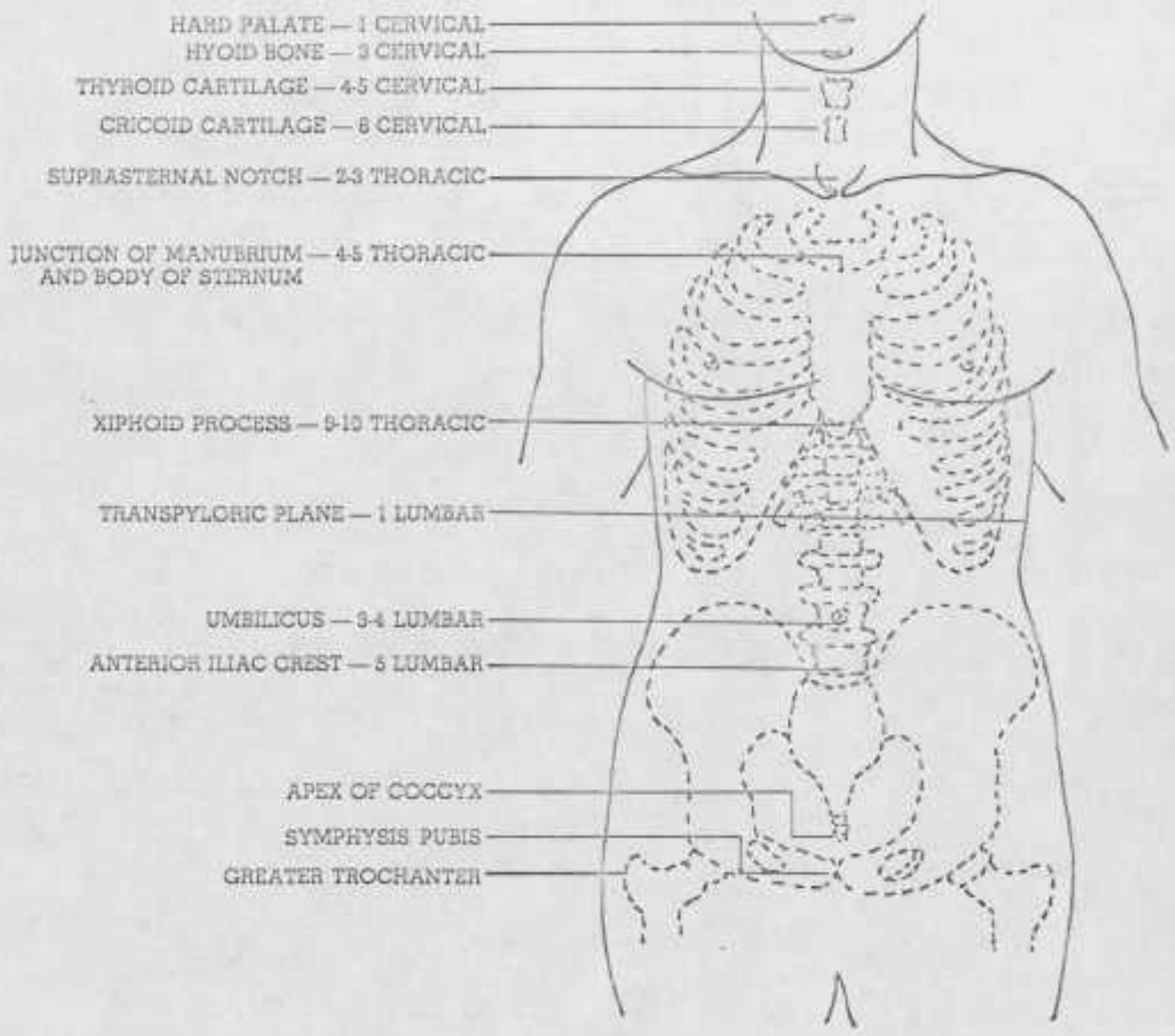

Pigure 1: Human anatomical landmarks.

Sfrom A Guide to Radiologieal Anatony, Pub. No. 69-3416C. Publishad by General Electric, Medical Systems Dept., Wilwaukee, Wis.) 


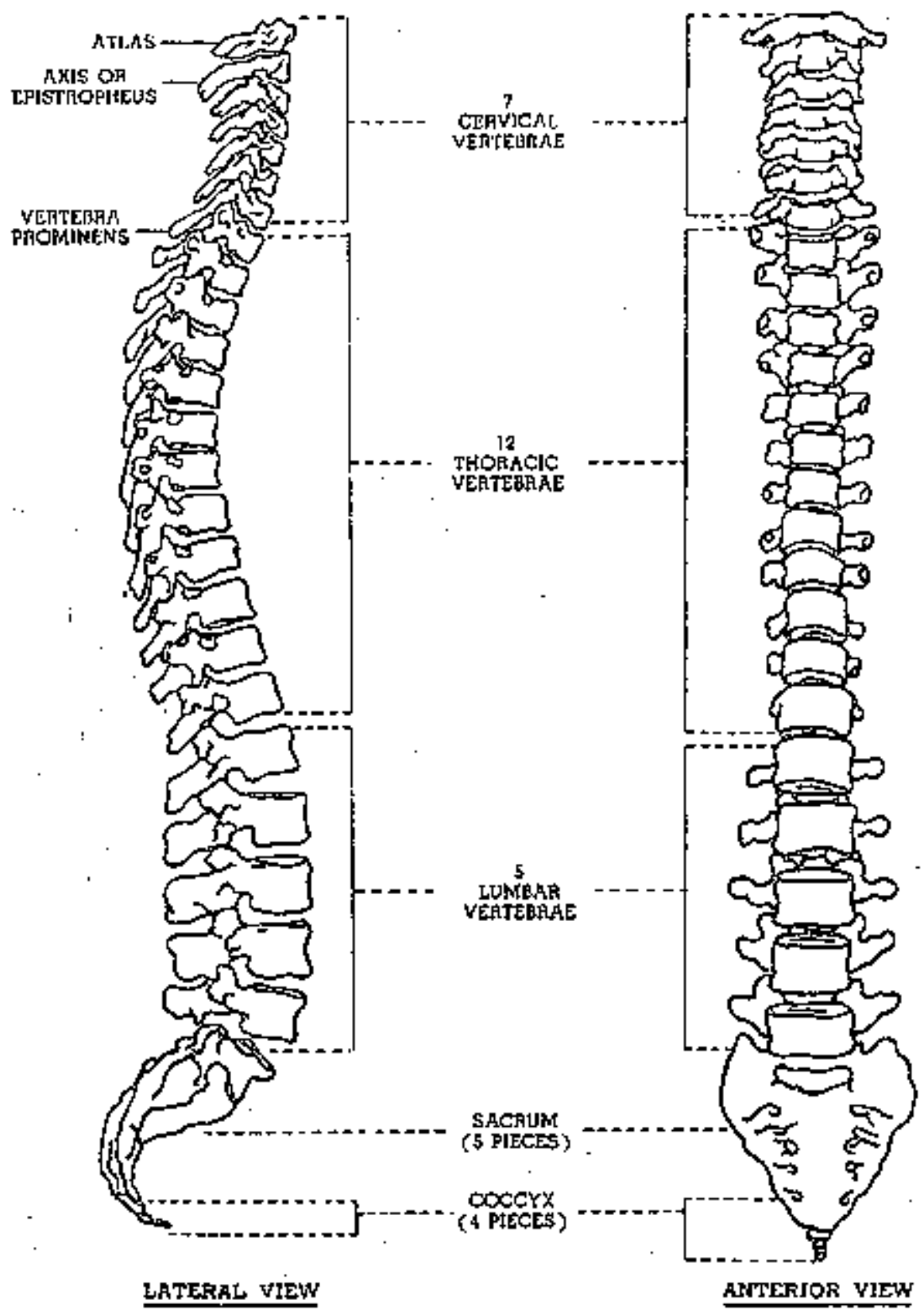

Figure 2: The vertebral column.

(from A Guide to Radiological Anatomy, Pub. No, 693416C. Published by Gereral Electric, Medical Systems Dept, , Milwaukee, Wis.) 


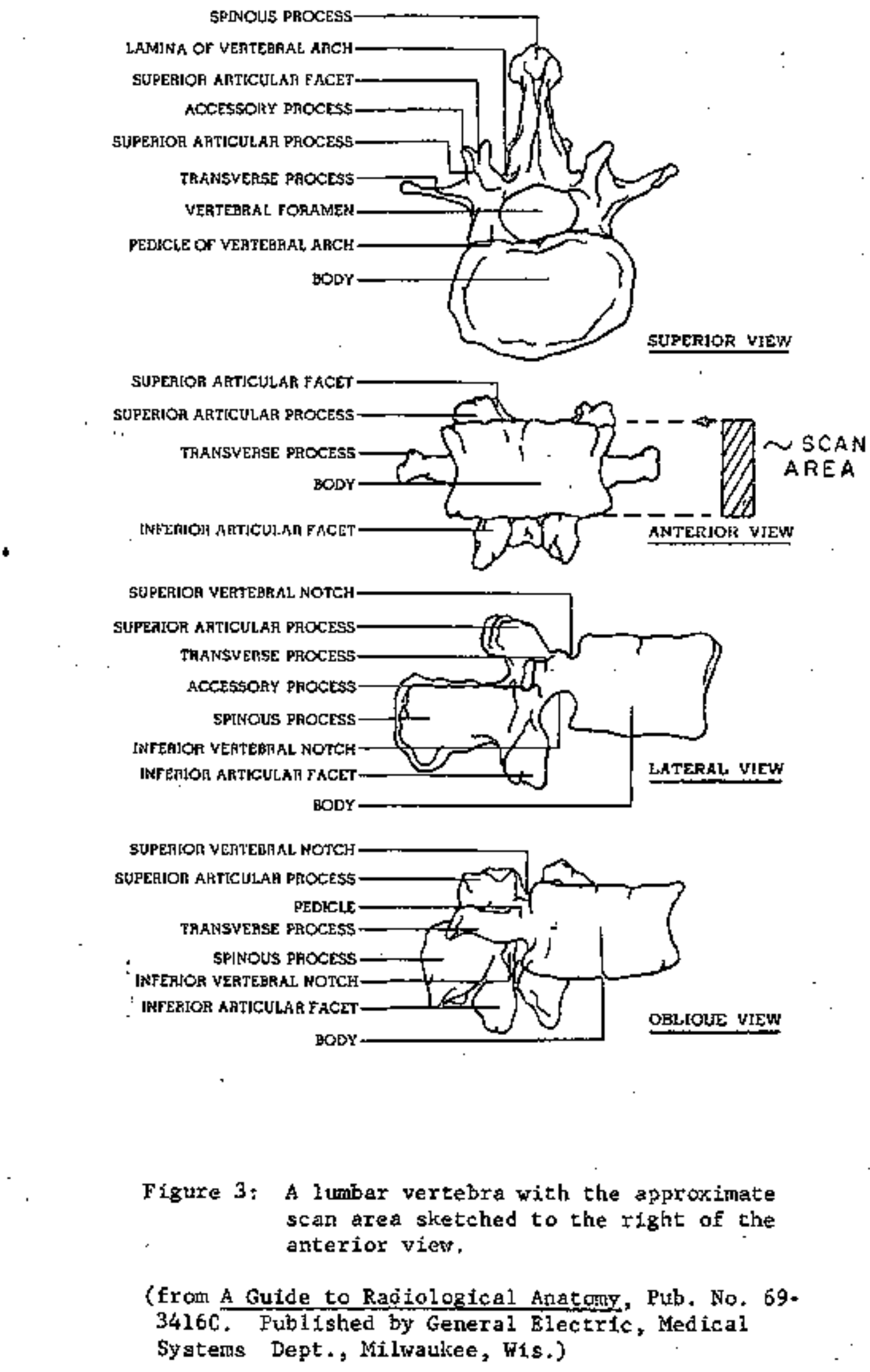




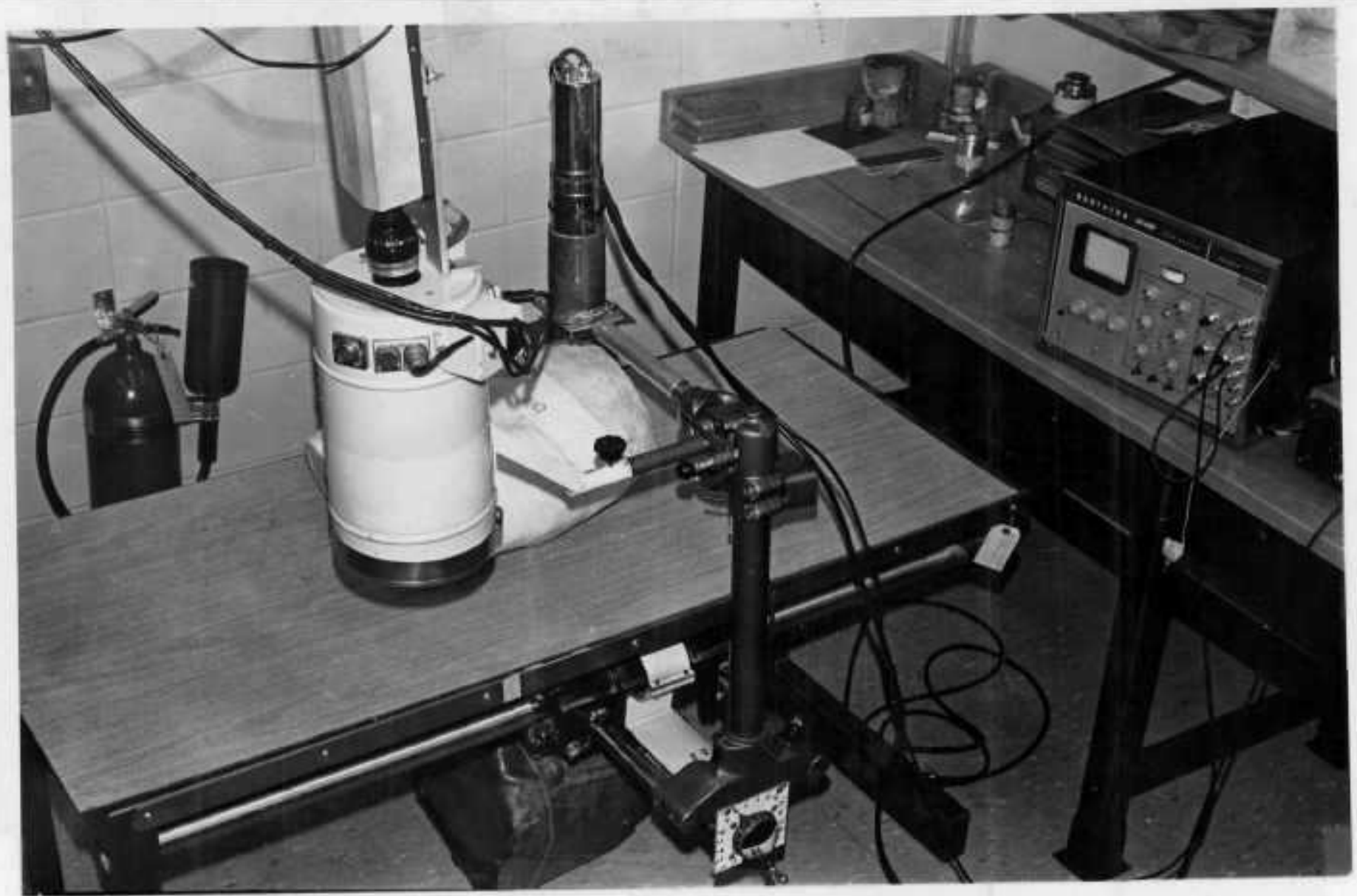

Figure 4: A photograph of the vertebral bone mineral measuring apparatus with the NaI(T1) crystal and photomultiplier tube in position over a torso phantom. The white cylinder to the left is the image intensifier. 


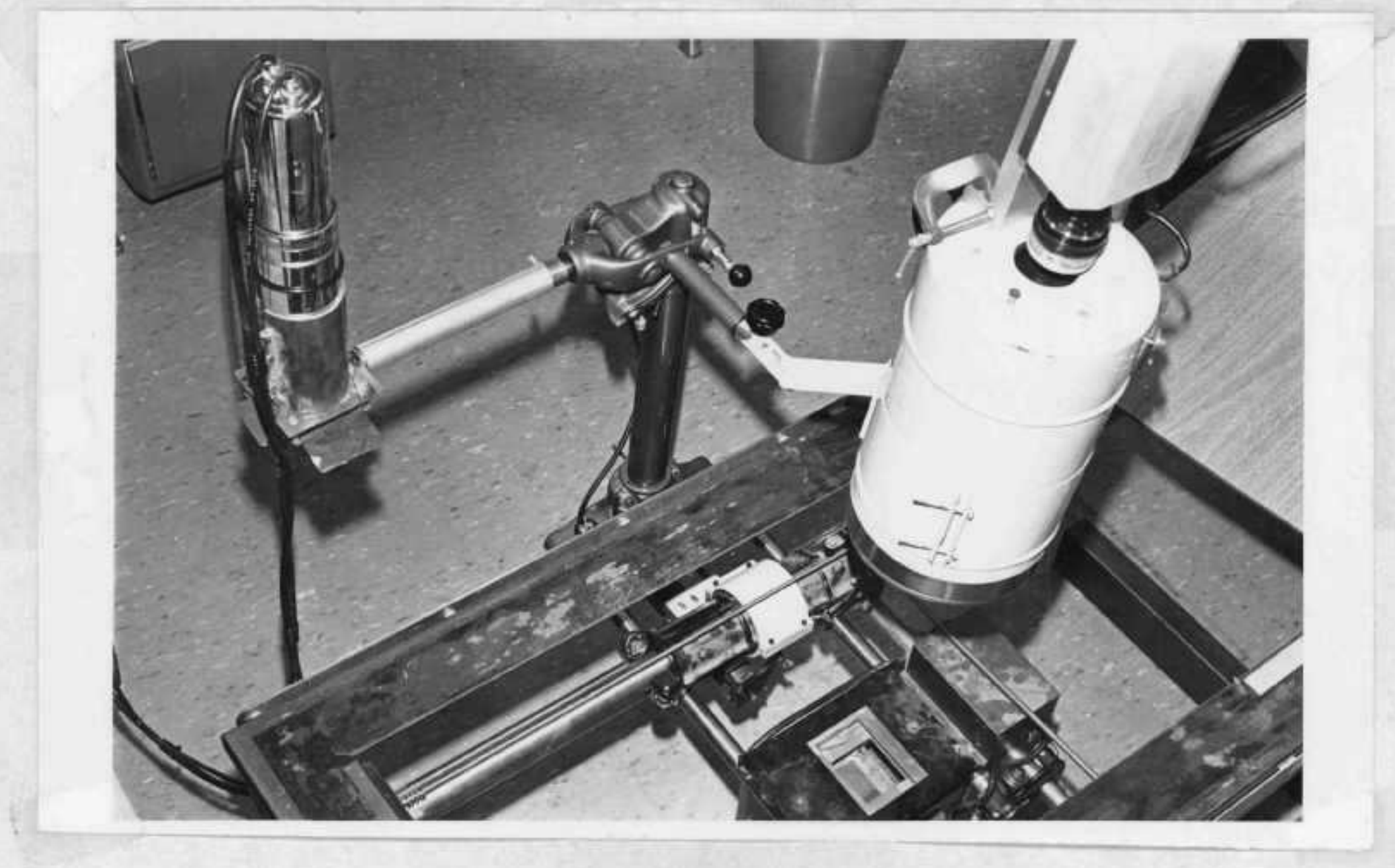

Figure 5: A photograph of the apparatus with the table top partially removed and with the image intensifier in position above the $\mathrm{x}$-ray tube. 
HIGH Voltage

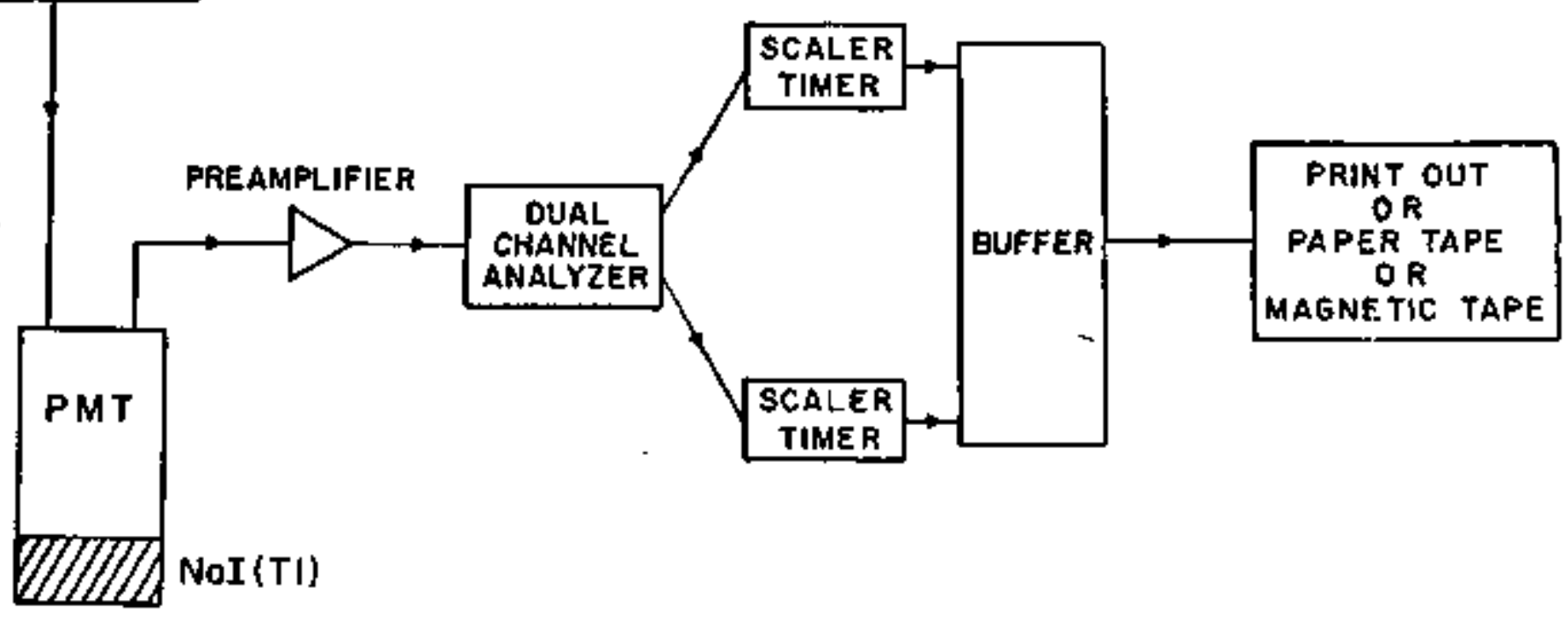

Figure 6: The basic electronic components needed to analyae a dichromatic transmisgion scan. 


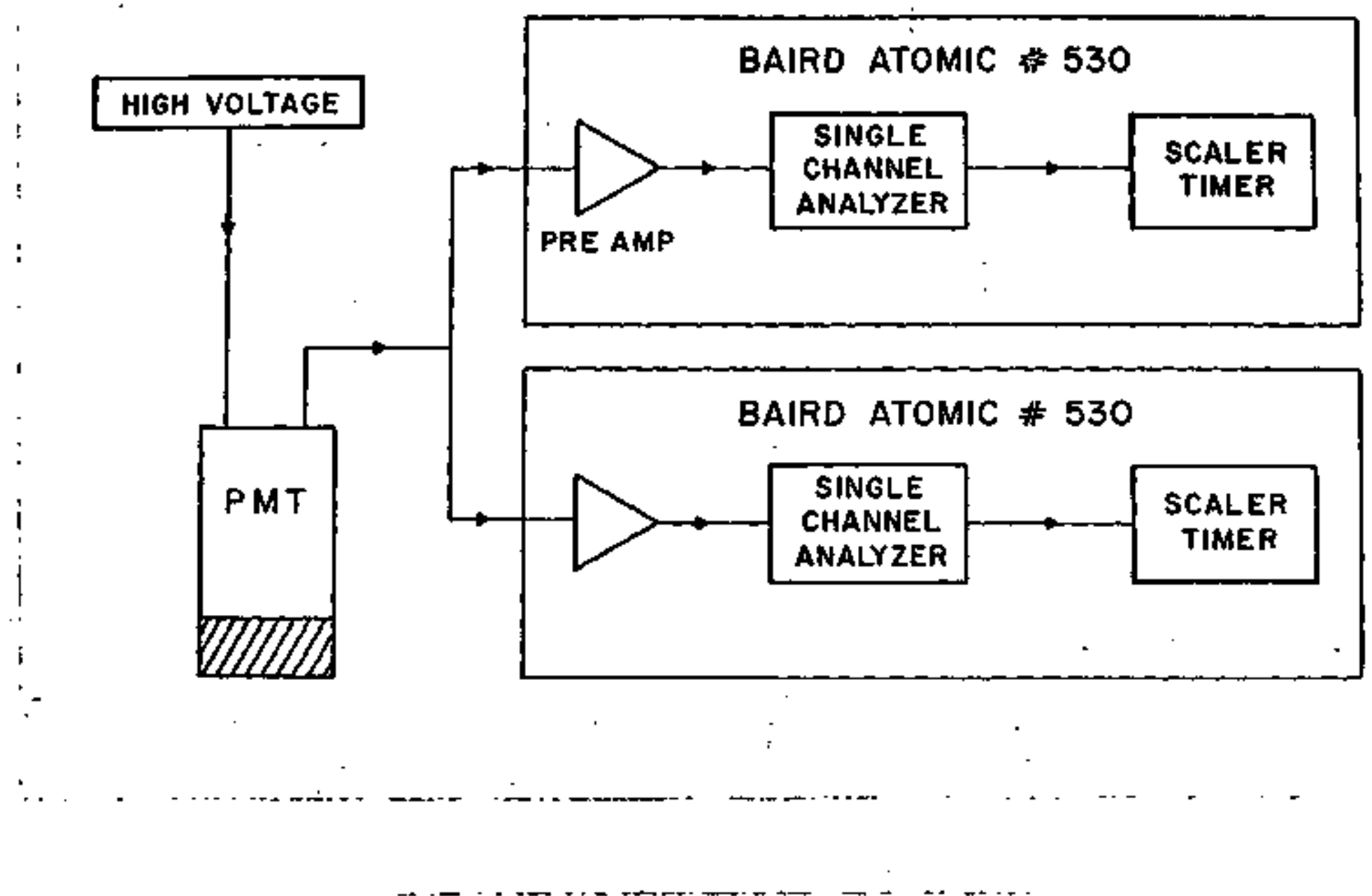

Figure 7: The electrical conponents used in preliminary measureuents. 


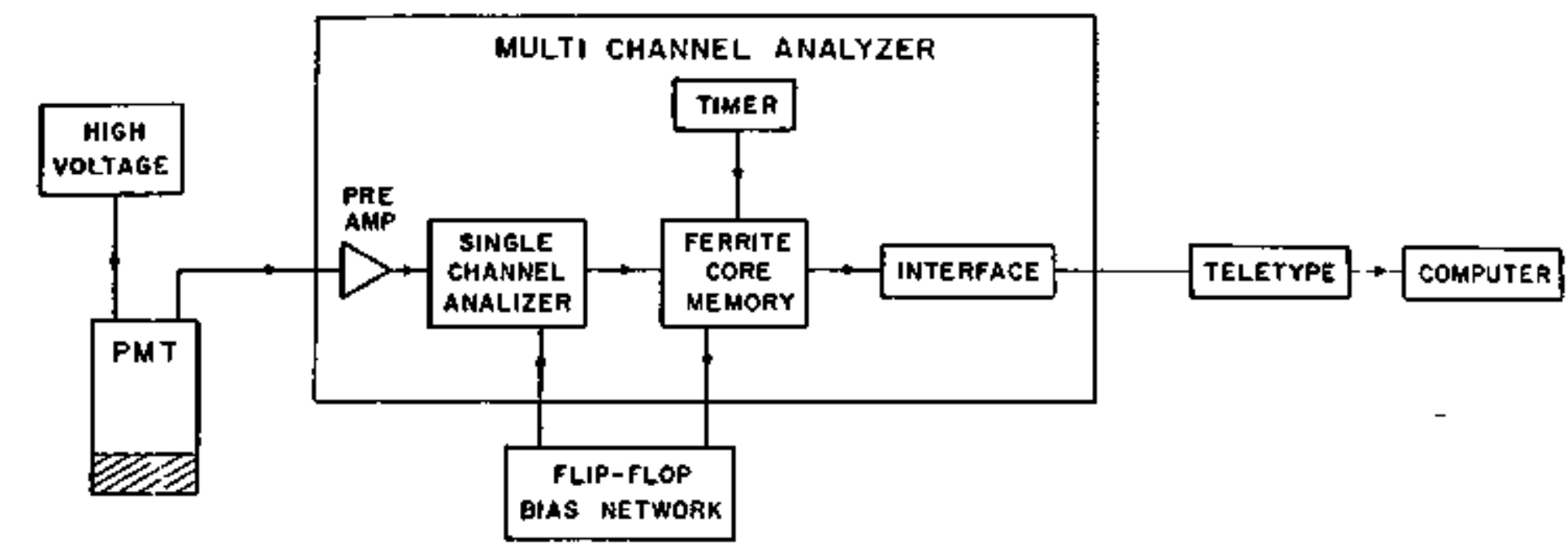

Figure 8: The electronic components currently being used. 


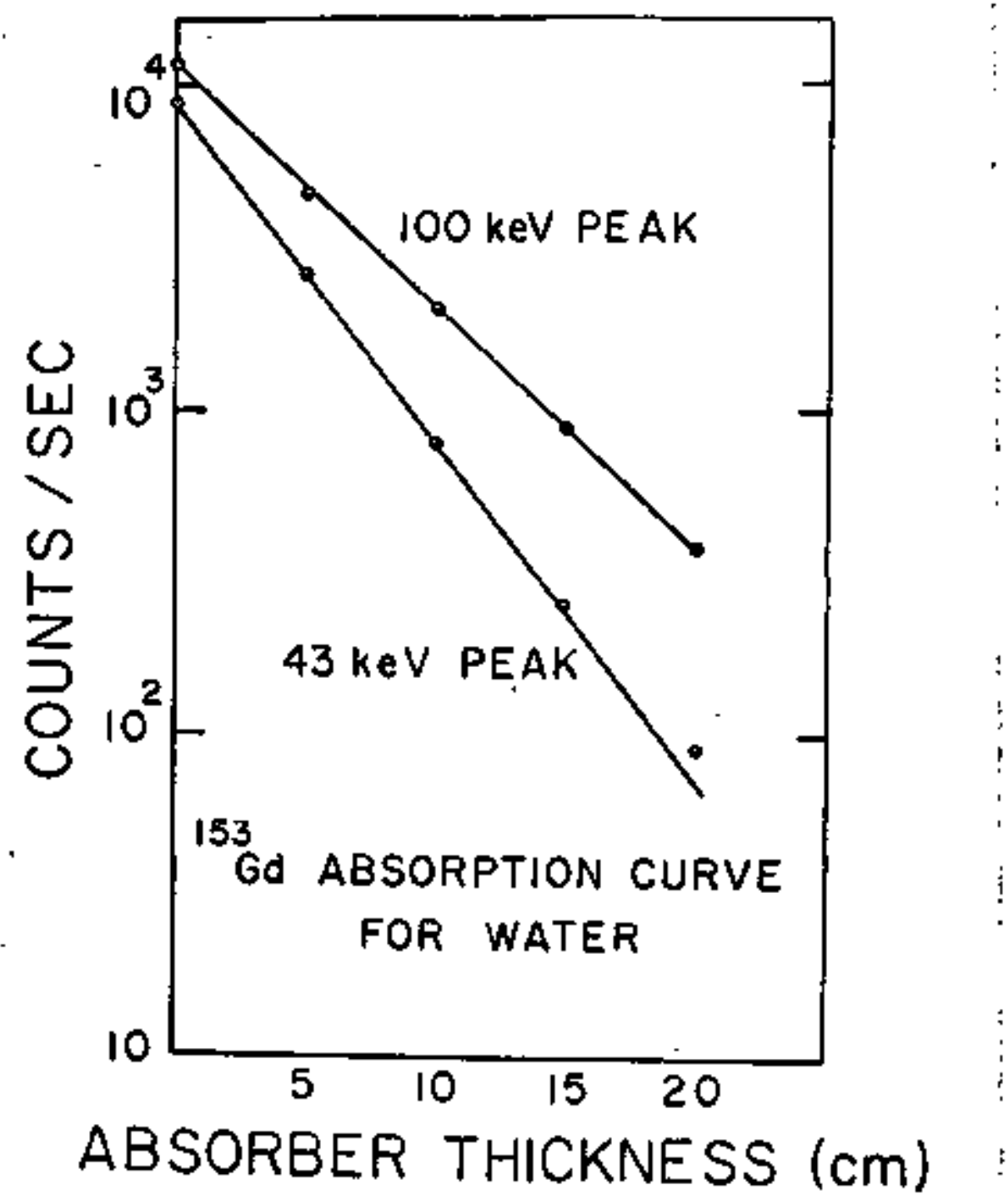

Figure 9as The photon absorption for the two principal energy peaks of $\mathrm{Gd}+153$ in vater. 


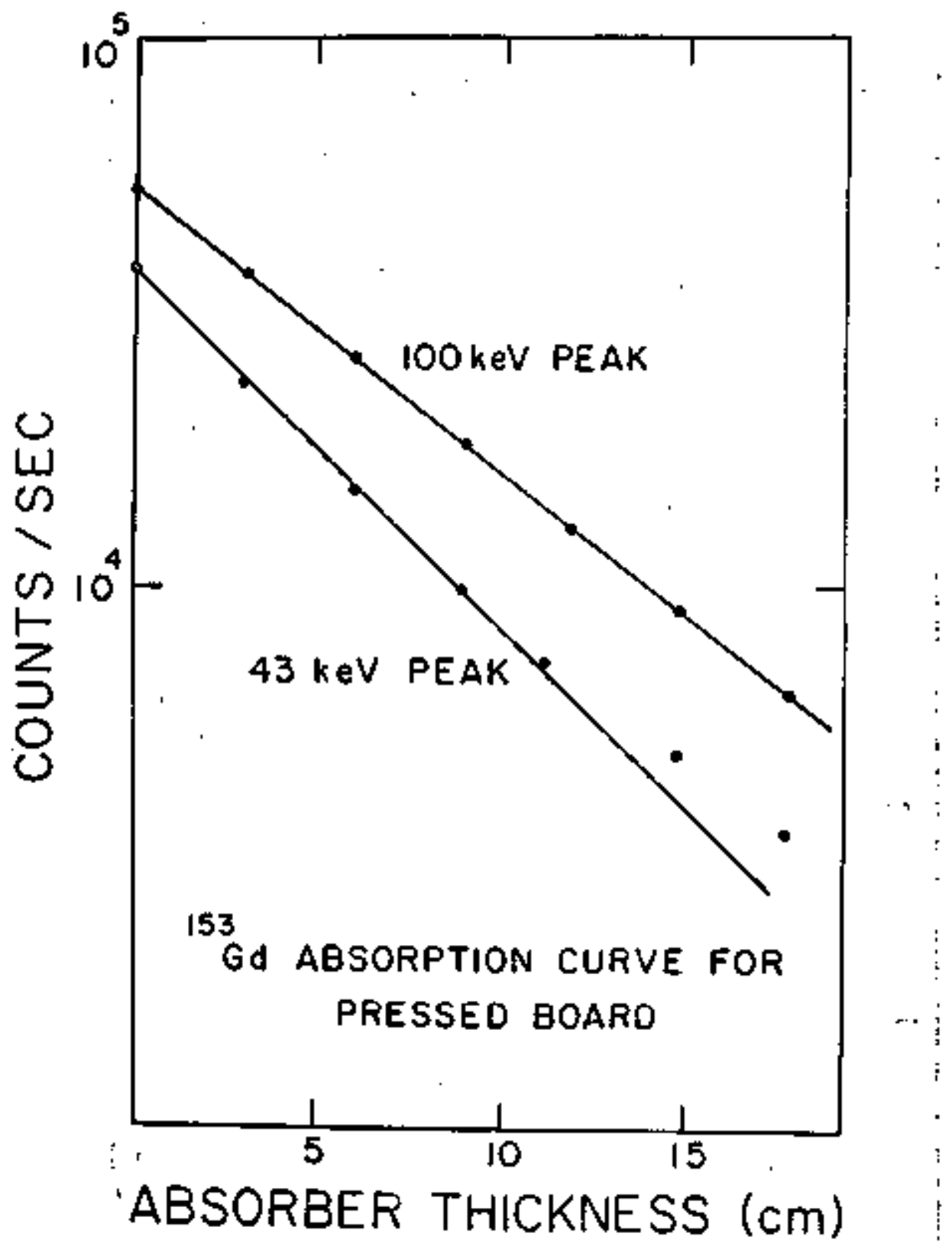

Figure 9b: The photon absorption for the two principal energy peaks of Gd-153 in presaed board. 


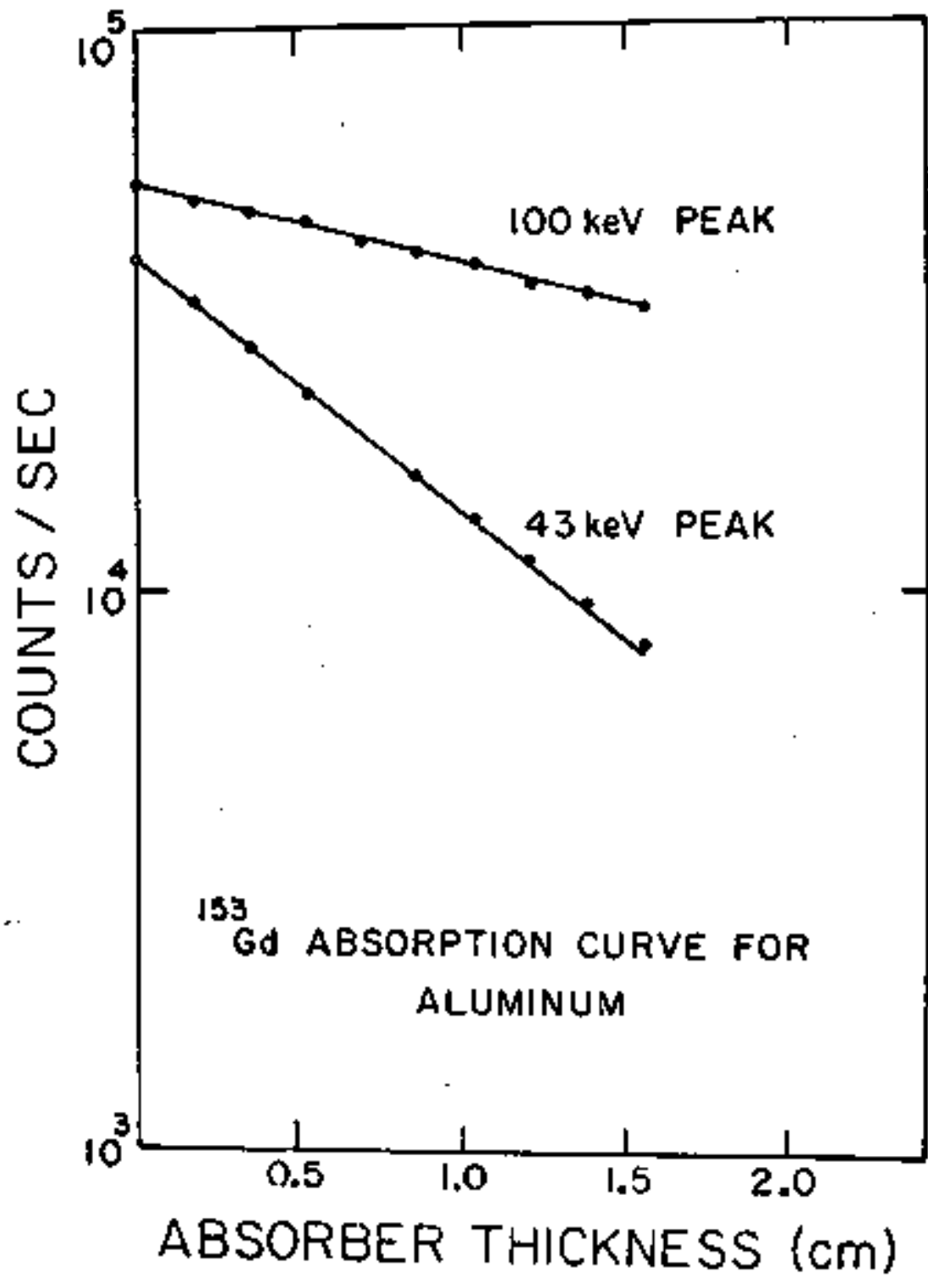

Figure 9c: The photon absorption for the two princfpsi energy peaks of Gd-153 in aluminum. 


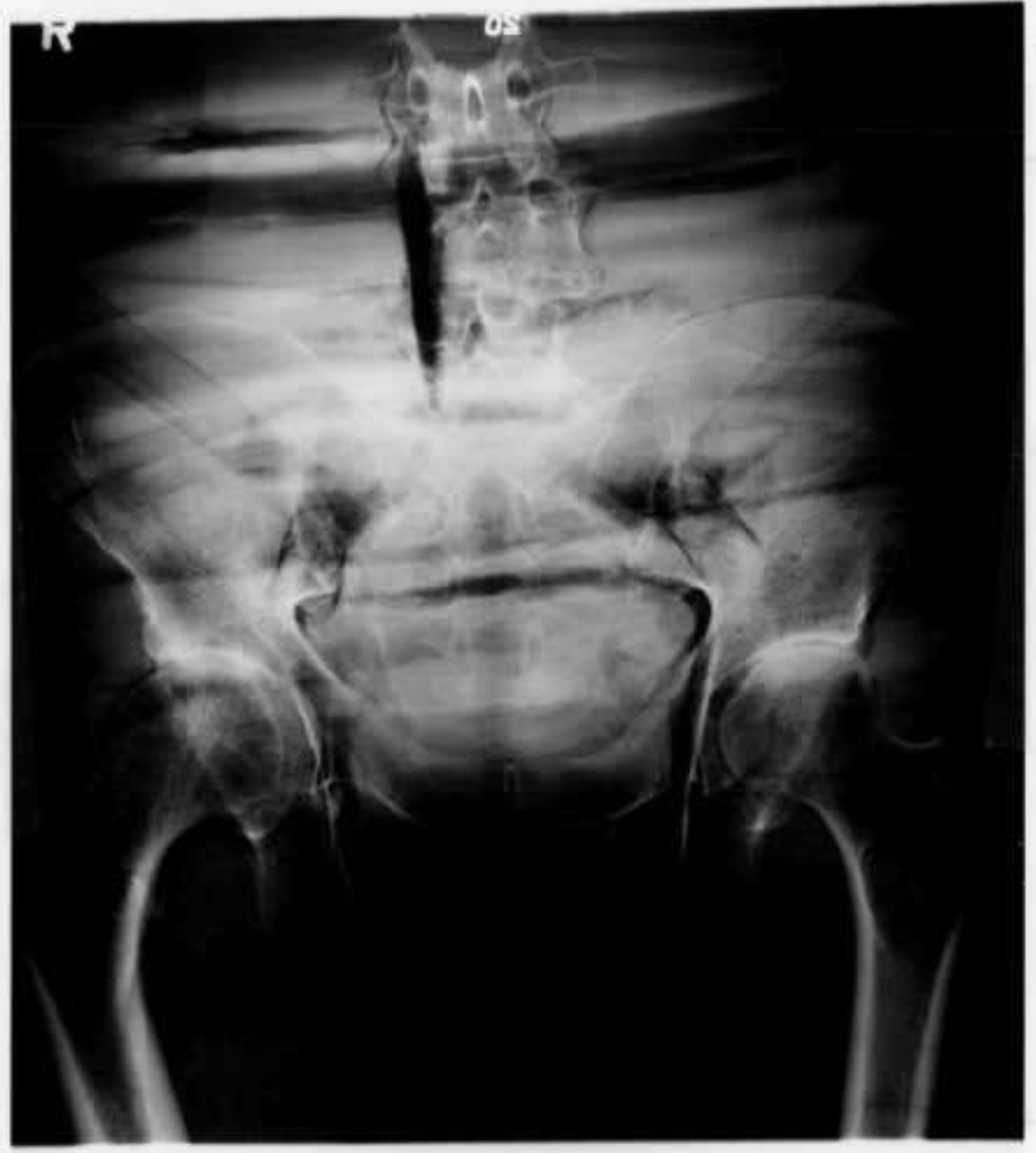

Figure 10: An x-ray of the torso phantom we used for preliminary scans. The top vertebral body in this photograph is $\mathrm{L}-3$. 


\section{3}
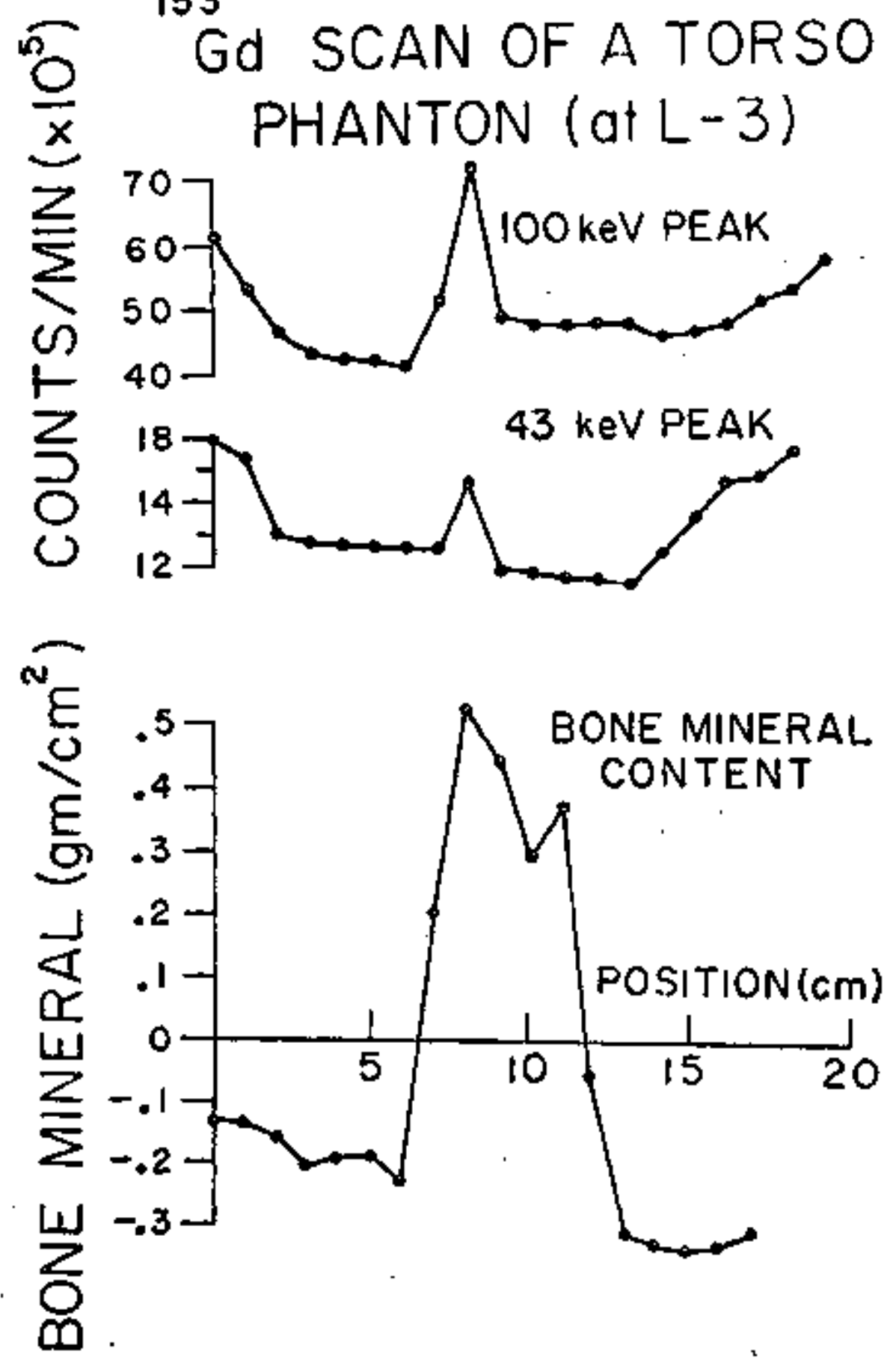

Figure 11: The data and calculated bone mineral for the phantom scan. 